\title{
Maximum Use of Online Universities Established by Group Companies
}

\author{
Kai Xue ${ }^{1, a}$, Shouchen $\mathrm{Xu}^{2, \mathrm{~b}}$, Xilin Zhang ${ }^{3, \mathrm{c}}$, Xiaojuan Han ${ }^{4, \mathrm{~d}}$ \\ ${ }^{1}$ State Grid Jilin Electric Power Company Limited Training Center, Changchun, Jilin 130022 , \\ China; \\ ${ }^{2}$ State Grid College of Management, Beijing 100085, China; \\ ${ }^{3}$ State Grid Jilin Electric Power Company Limited Changchun Power Supply Company, \\ Changchun, Jilin 130021, China; \\ ${ }^{4}$ Department of Control and Computer Engineering, University of North China Electric Power, \\ Beijing 102206, China. \\ a381093267@qq.com, bshouchen-xu@sohu.com, '985222805@qq.com, d1747860586@qq.com
}

Keywords: Central enterprise, online university, employee, on-the-job training.

\begin{abstract}
In order to enhance employees' technical and management skills to the best effect possible and maximize the returns on the investment of the Group in the online university, this paper discusses how to make the best use of the online university. Training managers should be familiar with the content and structure of the online university, have an idea of available courses closely related to their own organization and business, be clearly aware of relevant management regulations of the online university of the conglomerate, and implement these regulations within their own organizations according to specific conditions.
\end{abstract}

\section{Introduction}

To keep our practices abreast with the time, we need to study the laws underlying vocational training continuously ${ }^{[1,2,3,4,5]}$.

Most central conglomerates have their own online universities and courses available in these universities are usually offered, or the courseware is made, by experts in their respective fields. Courses go live on these platforms only when they have gone through rigorous review procedures. Therefore, the courses available at online universities of central conglomerates are generally reliable, advanced and authoritative; and constitute valuable training resources. It is the responsibility of training managers in lower-level companies of these central conglomerates to guide and organize employees to make full use of these resources based on their actual needs and within the framework of the existing management regulations of these online universities.

This is what we will set out to discuss below by referring to one such online university of a central conglomerates.

\section{Training Managers Should Be Familiar with the Content and Structure of the Online University}

The online university of this central conglomerate is consisted of the schools of human resources, leadership, finance and audit, asset management, development planning, engineering and construction, power grid operation, power grid maintenance, power marketing, information and communications, safety, international business, rules and regulations, and finance.

The home pages of these schools generally contain columns such as introduction, knowledge 
system, new courses, featured courses, hot courses, the course selection center, online examinations, online training, and knowledge center. These columns provide a wealth of courseware, exam information and training course information. The knowledge systems fall into the categories of operation, management, technology and skills. Employees mainly learn via the columns of new courses, featured courses, hot courses, course selection center, and knowledge center.

3. Training Managers Should Have an Idea of Available Courses Closely Related to Their Own Organization and Business

Training managers may find one ore more courses relevant to their own company or business in one or more schools of an online university. Since online courses are constantly updated and new courses become available one after another, training managers should check the website regularly to keep track of the many courses related to their own company and business, especially newly-released ones.

3.1 Training Managers Should Regular Look Through the Titles of the Online Courses Related to Their Own Company and Business. Course titles presents in concise manner the content and features of a course. Training managers, therefore, should regularly browse the titles of online courses related to their own company and business and decide if it is necessary to learn more about some the courses.

3.2 Training Managers Should Browse Summaries of Online Courses Closely Related to Their Own Company and Business. After looking through the titles of available courses and getting a rough idea of the relevance, training managers should proceed to page through the courseware and decide whether the course is truly related to their own company and business.

4. Training Managers Should Be Clearly Aware of the Management Regulations of the Online University

Training managers should be familiar with the online university's management regulations and credit rules.

4.1 Management Regulations of the Online University. In terms of online training course development, the management regulations mainly include rules on the organization and development efforts on the part of the conglomerate headquarters and provincial companies, as well as the knowledge contribution of individual employees.

In terms of online learning, specific requirements are laid out for different training models such as push-based learning, self-arranged learning and online training.

In terms of online examinations, the scope of online examination and certification is defined with specific operational arrangements made clear.

As for online learning forums, they are defined as platforms for information sharing and interactions.

As incentive and restraint mechanisms, online learning is clearly tied up with the promotion and career development of employees.

4.2 Credit Management. Credit is a quantitative representation of an employee's participation in online courses and his/her knowledge contribution. Credit points are calculated for every calendar year based on standards and they fall into three categories: course credit, contribution points and activeness points.

Employees earn credit point by taking online courses, passing examinations, developing 
standard or micro courseware, answering questions, and interacting with others in the learning community.

The total credit points of a year are one of the indicators for performance evaluation and expert evaluation of the year.

\section{Training Managers Should Be Able to Implement Regulations of the Online University}

5.1 Disseminate and implement the management regulations. Training managers should inform every employee of the management regulations of the online university via the OA system and apply them throughout their own company.

5.2 Create an atmosphere of online learning. Training managers should work with higher-level officials of the company to find specific ways to create an atmosphere for learning through the online university of the conglomerate, including putting forward specific requirements for learning through the online university, commending employees who are active and outstanding in online learning, and organizing learning competitions according to production needs.

5.3 List out new online courses available. Training managers may put up a list of new online courses on their company bulletin boards, display screens, and OA system, or announce it at pre- or post-shift meetings, send it through emails, or post it in WeChat or QQ learning group to let employees know what is available at the online university.

5.4 Work with higher-level officials to recommend some online courses. Training managers should select some courses as candidate online courses for recommendation and prepare relevant training plans for higher-level officials to review and prove, thus forming a final list of recommended courses and training plan.

This list and plan will then be disseminated via bulletin boards, display screens, OA system, pre- or post-shift meetings, emails, and WeChat or QQ learning groups.

5.5 Organize employees to take required or recommended online courses and relevant examinations. Training managers should notify employees of what courses they are required to take via bulletin boards, display screens, OA system, pre- or post-shift meetings, and WeChat or QQ learning groups, and remind them to take relevant examinations.

They should organize employees to take online courses, sign up for training sessions, and take the relevant examinations to check how well they learn based on the approved list of recommended courses and training plan.

5.6 make full use of the teaching resources on the network university in the winter training and professional knowledge competition and other activities

The winter training, professional knowledge competition has become frequent activities for Central Enterprise Group Staff job training. As the northern winter climate is not conducive to engineering construction, commissioning experiments and other work carried out. Production activities in a relatively off-season period, the work is given priority to with operation maintenance, that is the best time to focus on training for a period of time. Professional knowledge competition has a strong incentive effect for staff initiative learning, as long as the organization properly will receive good results. "Competitions to promote training" has become a common form of training.

Whether it is winter training or professional knowledge competition, the work program, training time, specific arrangements, and incentive measures should be detailed arrangement.Due to the correctness, advancedness and authoritativeness of the training courseware, the content of training should be selected from the network university. The following guidelines apply to selecting a course. First, to meet the specific training requirements of the higher authorities. The second is conform to the knowledge structure of unit or department staff and the actual situation of job requirements. The 
third is knowledge and technical reserves for the new technology and new equipment that may have to cope with in the future. The fourth is to meet the specific requirements of knowledge competition work.

5.7 Incentives and restraints for taking recommended online courses. Companies or departments that have regular training examinations should include the content of the recommended courses in the examinations; those that do not have such examinations should give incentives to employees who complete the recommended courses on time.

5.8 Encourage employees to develop online courses. The conglomerate encourages individuals to contribute their knowledge and such contribution will be shared in the knowledge center after it is approved by the management authority of the online university. Individual employees may make their contribution mainly by providing online courseware, exam questions, and cases.

\section{Conclusion}

Training courses offered at the online university of a conglomerate are authoritative and of great diversity. Encouraging employees to learn such courses to an appropriate extent will greatly improve the effectiveness of vocational training and maximize the returns on the conglomerate's investment in creating an online university.

\section{References}

[1] Zhang Xilin, Xu Shouchen, On Research and Practice of Building a Harmo Progr \& Pro Team with Technological Innovation as Management Media [C] 2nd International Conference on Management Science and Industrial Engineering, 2013, pp.514-518.

[2] Zhang Xilin, Xu Shouchen, Innovation Research on Learning from Lv Qingsen Activities by Grass-root Party Organizations [C] 2nd International Conference on Management Science and Industrial Engineering, 2013, pp.510-514.

[3] Zhang Xilin, Zhang Hui, Contest of Dispatch Departments in Power Supply Enterprises [J], China Electric Power Education, vol. 35, pp.243-244, 2010.

[4] Zhang Xilin, Xu Shouchen, Research on Innovative Training Methods for Frontline Employees in High-Technology Department of Power Enterprises and the Practices [C] 2nd International Conference on Management Science and Industrial Engineering, 2013, pp.518-521.

[5] Zhang Xilin, Yang Guiying, Liu Xiaowei. Training Management Experience of Power Dispatching Department of Power Supply Enterprises [J]. China Electric Power Education, vol. 29, pp.48-50, 2010. 